\title{
Comparison of the osmoregulatory capabilities among three amphibious sea snakes (Laticauda spp.) in Taiwan
}

\author{
Yuan-Cheng Cheng ${ }^{1}$, Ming-Chung Tu' ${ }^{1}$, Jyuan-Ru Tsai ${ }^{2}$, Hui-Chen Lin ${ }^{2,3}$ and Li-Yih Lin ${ }^{1 *}$
}

\begin{abstract}
Background: The three species of amphibious sea snakes (Laticauda semifasciata, L. laticaudata, and L. colubrina) in Taiwan were described as having different habitat affinities from terrestrial to marine. In this study, the osmoregulatory capabilities of three species were compared to test if their capabilities were associated with different habitat affinities.

Results: The sea snakes were transferred from a terrestrial environment to freshwater (FW) or seawater (SW) for 1 week, and then, $\mathrm{Na}^{+} / \mathrm{K}^{+}$-ATPase (NKA) activities of the salt gland (sublingual glands) and kidneys, the water content of the muscles, the body fluid osmolality, and $\mathrm{Na}^{+}, \mathrm{Cl}^{-}$, and $\mathrm{K}^{+}$concentrations were measured. Results showed that the body fluid osmolality, $\mathrm{Na}^{+}$and $\mathrm{Cl}^{-}$levels, and muscle water content of most marine species, L. semifasciata, remained relatively constant, and the NKA activity of its salt gland was approximately threefold higher than those of L. laticaudata and L. colubrina. In both L. semifasciata and L. laticaudata, NKA activities of the salt glands were higher in SW than in FW; however, no significant change was found in L. colubrina (the most terrestrial species).
\end{abstract}

Conclusions: This study suggests that the NKA activity of the sublingual gland is associated with salt excretion, and the three species possess different osmoregulatory strategies which are associated with their habitat affinities.

Keywords: Sea snake; Salt gland; Osmoregulation; $\mathrm{Na}^{+} / \mathrm{K}^{+}$-ATPase

\section{Background}

Secondary marine animals are groups that originated from freshwater (FW) or terrestrial habitats and have recolonized the marine environment (Vermeij and Dudley 2000; Willmer et al. 2004). When a marine invasion occurs, salinities of marine environments pose a strong physiological barrier to these animals. The osmolality of seawater (SW) is appropriately $1,000 \mathrm{mOsm} / \mathrm{kg}$; however, most terrestrial vertebrates maintain their body fluids at appropriately 250 to $450 \mathrm{mOsm} / \mathrm{kg}$. In hypertonic marine environments, vertebrates experience challenges of dehydration and salt accumulation. For successful habitation, various osmoregulatory tissues and organs have evolved in marine vertebrates in response to osmotic challenges. Salt glands are specialized organs for salt secretion in marine vertebrates including birds, reptiles, and elasmobranches

\footnotetext{
* Correspondence: linly@ntnu.edu.tw

${ }^{1}$ Department of Life Science, National Taiwan Normal University, Taipei 116, Taiwan

Full list of author information is available at the end of the article
}

(Schmidt-Nielsen 1958, 1960; Oguri 1964). Nasal salt glands and rectal salt glands were respectively described in marine birds and marine elasmobranches (Burger 1965; Peaker 1971). In reptiles, several kinds of salt gland are found: lachrymal glands in sea turtles and terrapins (Dunson 1970; Hudson and Lutz 1986), nasal glands in marine iguanas (Dunson 1969), lingual glands in crocodilians (Taplin and Grigg 1981), and sublingual and premaxillary glands in marine snakes (Dunson et al. 1971; Dunson and Dunson 1973, 1979). In marine teleosts, the gills are the major organ for salt excretion (Evans et al. 2005).

The physiological mechanisms of salt secretion were explicitly studied in the gills of marine teleosts (Marshall 2002; Evans et al. 2005; Hwang and Lee 2007) and in the salt glands of marine birds and elasmobranches (Riordan et al. 1994; Silva et al. 1997; Shuttleworth and Hildebrandt 1999; Hildebrandt 2001). In the gills of marine teleosts, mitochondrion-rich cells (MRCs) actively secrete internal $\mathrm{Cl}^{-}$and $\mathrm{Na}^{+}$. Three ion transport proteins were found to play critical roles in salt secretion: $\mathrm{Na}^{+} / \mathrm{K}^{+}$-ATPase (NKA), 
the $\mathrm{Na}^{+} / \mathrm{K}^{+} / 2 \mathrm{Cl}^{-}$cotransporter (NKCC), and the cystic fibrosis transmembrane conductance regulator (CFTR)-like $\mathrm{Cl}^{-}$channel (Marshall 2002). Basolateral NKA pumps $\mathrm{Na}^{+}$ out of MRCs, and the accumulated $\mathrm{Na}^{+}$is extruded by an electrochemical gradient through a paracellular pathway. The $\mathrm{Na}^{+}$gradient of MRCs drives the NKCC to carry $\mathrm{Na}^{+}$, $\mathrm{K}^{+}$, and $2 \mathrm{Cl}^{-}$into MRCs. Then, the accumulated $\mathrm{Cl}^{-}$ in MRCs diffuses out of cells via the $\mathrm{Cl}^{-}$channel on the apical membrane (Marshall 2002; Evans et al. 2005; Hwang and Lee 2007). In the salt glands of marine birds and elasmobranches, the three transport proteins of NKA, NKCC, and CFTR were also identified in secretory principal cells, and their mechanism is similar to that of the fish gills (Hildebrandt 2001).

The sublingual gland of sea snakes secretes a concentrated salt solution after salt loading, suggesting that it is the salt gland of the sea snakes (Dunson et al. 1971). The sublingual gland lies on the ventrolateral surface of the tongue sheath, and its morphology is similar to those of the other salt glands in marine birds and elasmobranches (Babonis et al. 2009). Recently, NKA and the NKCC were immunolocalized to the basolateral membrane of principal cells in the sublingual gland of three species of the sea snakes (Laticauda spp.), suggesting that the mechanism of salt secretion in sea snakes is similar to that of the other marine vertebrates (Babonis et al. 2009). The three species of amphibious sea snakes (Elapidae: Laticaudinae) are distributed at Orchid Island (Lanshu in Chinese) and Green Island (Ludao in Chinese) off the southeast coast of Taiwan. They were described as having different habitat affinities in previous studies (Lillywhite et al. 2008, 2009). Laticauda semifasciata (Reinhardt) is the most marine species. On the contrary, L. colubrina (Schneider) is the most terrestrial species (Shetty and Shine 2002). L. laticaudata (Linnaeus) has an intermediate habitat affinity. Lillywhite et al. (2008) measured the dehydration rates of the three species in air and found that the rate in $L$. colubrina (the most terrestrial species) was lower than those in the other two species. Moreover, the skin permeability to water also differed among these species (Lillywhite et al. 2009), suggesting that their water regulation is associated with their habitat affinities (Lillywhite et al. 2008 2009). However, the osmoregulatory capabilities of the three species in response to osmotic challenges have not been fully investigated. In this study, we attempted to further examine their osmoregulation and test if there is an association between their physiological performances and habitat affinities. NKA activities (which are a parameter for the activity of salt-secreting organs) of the salt gland and kidney, body fluid osmolality, ion concentrations, and muscle water content were analyzed in the three species after subjecting them to hypertonic (SW) and hypotonic (FW) challenges.

\section{Methods}

\section{Animal collection and experimental protocols}

Three species of adult male sea snakes were mainly collected from Orchid Island, Taiwan, and a few L. laticaudata and L. colubrina were collected from Green Island, Taiwan, in August to September 2009 and April to August 2010. The animals were captured by hand in shallow coastal inlets and were transported to the laboratory of National Taiwan Normal University, Taipei, Taiwan. The body length and weight of the three species were respectively $104.2 \pm 1$ $\mathrm{cm}$ and $532.3 \pm 18 \mathrm{~g}$ for $L$. semifasciata, $91.4 \pm 1 \mathrm{~cm}$ and $165.0 \pm 7 \mathrm{~g}$ for L. laticaudata, and $89.7 \pm 1.7 \mathrm{~cm}$ and $200.6 \pm 11 \mathrm{~g}$ for $L$. colubrina. The animals were kept in plastic tanks $(36.5 \times 23.3 \times 15.6 \mathrm{~cm}$, one individual per tank). Each tank contained a plastic basin $(15 \times 20 \times 8 \mathrm{~cm})$ filled with dechlorinated tap water for drinking and soaking during 1 week of acclimation. Then, five to eight individuals of each species were initially sampled (representing the pretransfer condition), and the remainder were randomly transferred to FW (dechlorinated tap water) or 32 ppt SW (prepared using artificial sea salt, Instant Ocean $^{\mathrm{Tm}}$ powder, Crystal Sea, Baltimore, MD, USA). The salinity of the water was monitored with a refractometer (PAL-06S, Atago, Tokyo, Japan). During FW or SW acclimation, the animals were confined to the water but could expose their head to breathe. Five to eight individuals of each species were sampled after 7 days of acclimation in FW or SW. In a preliminary study, several individuals were acclimated to FW or SW for up to 14 days, and we found that some of them became inactive probably due to starvation and osmotic stress. Therefore, we chose 7 days of acclimation for sampling. The animals were not fed, and the water temperature was kept at $27^{\circ} \mathrm{C}$ with a 12-h light and 12-h dark photoperiod during the experimental period. In this study, all animals were treated in accordance with the protocols approved by the Animal Care and Use Committee of National Taiwan Normal University (permit no. 93013).

\section{Tissue sampling}

The animals were anesthetized with ice and euthanized by decapitation, and their body fluid was collected from the opening of vessels into microtubes for analysis of osmolality and ionic concentrations. The sublingual gland and kidneys were excised and stored at $-80^{\circ} \mathrm{C}$ for NKA activity measurements. A lateral trunk muscle was excised for water content measurement.

\section{Measurement of body fluid osmolality and ionic concentrations}

The collected body fluid was immediately centrifuged at $6,000 \times g$ for $5 \mathrm{~min}$, and aliquots of fluid were stored at $-20^{\circ} \mathrm{C}$ for the analysis of osmolality and ionic concentrations. The osmolality was determined with a vapor pressure 
osmometer (Wescor Model 5520, Logan, UT, USA), and $\mathrm{Na}^{+}, \mathrm{Cl}^{-}$, and $\mathrm{K}^{+}$concentrations were determined by a biochemical analyzer (Vitro 5.1 FS, Johnson \& Johnson, New Brunswick, NJ, USA).

\section{Water content of the muscle}

Surface water and blood on the muscle tissues were cleaned off with tissue paper. The water content was determined by calculating the percentage weight loss after drying the tissues at $100^{\circ} \mathrm{C}$ for 3 days (Huang et al. 2010).

\section{Protein extraction from the salt gland and kidneys}

Salt gland tissues and kidneys were separately homogenized in a homogenizing medium consisting of $25 \mathrm{mM}$ Tris-HCl (Bio-Rad, Hercules, CA, USA), 0.25 mM sucrose (Merck, Darmstadt, Germany), 20 mM EDTA (Sigma, St Louis, MO, USA), and 0.4\% sodium deoxycholate (Sigma, $\mathrm{pH}$ 7.4), which contained protease inhibitors of $3.31 \mathrm{mM}$ antipain (Sigma), $2.16 \mathrm{mM}$ leupeptin (Sigma), and 63.86 $\mathrm{mM}$ benzamidine (Sigma) in an aprotinin saline solution (5 to 10 trypsin inhibitor units/ml, Sigma) using an ultrasonic processor. The protease inhibitor and homogenizing medium volumetric ratio was 1:200. Homogenates were first centrifuged at $4^{\circ} \mathrm{C}$ and $6,000 \times g$ for $15 \mathrm{~min}$ and then centrifuged at $4^{\circ} \mathrm{C}$ and $20,000 \times g$ for $20 \mathrm{~min}$. Fresh supernatants were immediately analyzed for NKA activity. Then, $5 \mu \mathrm{L}$ of the supernatant was further diluted to $50 \mu \mathrm{L}$ with deionized water. An aliquot of $10 \mu \mathrm{L}$ of this mixture was further diluted to $800 \mu \mathrm{L}$ with deionized water. This diluted supernatant was well mixed with $200 \mu \mathrm{L}$ of protein assay solution (Bio-Rad). Total protein levels were determined with a spectrophotometer (U-2001, Hitachi, Japan) at a wavelength of $595 \mathrm{~nm}$.

\section{NKA activities of the salt gland and kidneys}

The method of measuring NKA activity was as described in a previous study (Tsai and Lin 2007). Briefly, NKA activity was assayed in a ouabain-containing reaction medium of $20 \mathrm{mM}$ imidazole (Sigma), $130 \mathrm{mM} \mathrm{NaCl}$ (Merck), $10 \mathrm{mM} \mathrm{MgCl}_{2}$ (Merck), and $1 \mathrm{mM}$ ouabain (Sigma) at $\mathrm{pH} 7.4$ and ouabain-free reaction medium of $20 \mathrm{mM}$ imidazole, $100 \mathrm{mM} \mathrm{NaCl}, 30 \mathrm{mM} \mathrm{KCl}$ (Merck), and $10 \mathrm{mM} \mathrm{MgCl}$ at $\mathrm{pH}$ 7.4. The mixture was supplemented with $100 \mu \mathrm{L}$ of an ATP stock solution (25 mM Na $\mathrm{maTP}_{2}$ Sigma) and incubated at $37^{\circ} \mathrm{C}$ for 15 min. Ten microliters of protein extraction was added to $400 \mu \mathrm{L}$ of reaction medium. The reaction was stopped by adding $200 \mu \mathrm{L}$ of an ice-cold 30\% trichloroacetic acid (TCA) stock solution (Merck). The reaction mixture was centrifuged at $1,640 \times g$ and $4^{\circ} \mathrm{C}$ for $10 \mathrm{~min}$, and the supernatant $(500 \mu \mathrm{L})$ was collected. The NKA activity was calculated as the difference in the inorganic phosphate $(\mathrm{Pi})$ content between the ouabain-containing and ouabain-free reaction solutions. The Pi concentration was determined by Boting's color reagent $(560 \mathrm{mM}$ $\mathrm{H}_{2} \mathrm{SO}_{4}, 8.1 \mathrm{mM}$ ammonium molybdate tetrahydate, and $176 \mathrm{mM} \mathrm{FeSO}$, all from Sigma) with a spectrophotometer. Ice-cold Boting's color reagent $(1,000 \mu \mathrm{L})$ was added to the supernatant $(500 \mu \mathrm{L})$ and incubated in a $20^{\circ} \mathrm{C}$ water bath for $20 \mathrm{~min}$, and the absorbance of the solution was measured at $700 \mathrm{~nm}$. The NKA activity was expressed as $\mu \mathrm{mol} \mathrm{Pi/mg/protein/h}$.

\section{Statistical analysis}

All values are presented as the mean \pm standard error of the mean (SEM). Values were analyzed by a $t$ test or one-way analysis of variance (ANOVA) and Tukey's post hoc honest significant difference (HSD) test conducted using JMP 7 (SAS Institute, Cary, NC, USA). Differences were considered statistically significant for $p$ values of $<0.05$.

\section{Results \\ Body fluid osmolality}

In the most marine species, L. semifasciata, the body fluid osmolality was $301.9 \pm 3 \mathrm{mOsm} / \mathrm{kg}$ before transfer (Figure 1A), and no significant change was found after FW or SW acclimation $(302.5 \pm 2 \mathrm{mOsm} / \mathrm{kg}$ in FW and $310.8 \pm 4 \mathrm{mOsm} / \mathrm{kg}$ in SW; $F_{2,21}=2.16, p=0.14$, ANOVA). In L. laticaudata, the osmolality was $302.4 \pm 3$ $\mathrm{mOsm} / \mathrm{kg}$ before transfer (Figure $1 \mathrm{~B}$ ), and it significantly increased to $324.1 \pm 3 \mathrm{mOsm} / \mathrm{kg}(p<0.001$, Tukey's HSD) after SW acclimation but did not significantly change after FW acclimation $(308.4 \pm 3 \mathrm{mOsm} / \mathrm{kg} ; p=0.18$, Tukey's HSD). In the most terrestrial species, L. colubrina, the osmolality was significantly higher than those of the other two species before transfer $(p<0.001$, Tukey's HSD) at $332.4 \pm 1 \mathrm{mOsm} / \mathrm{kg}$ (Figure 1C), and it slightly increased to $339.2 \pm 3 \mathrm{mOsm} / \mathrm{kg}$ ( $p=0.1$, Tukey's HSD) after SW acclimation and slightly decreased to $325.7 \pm 1 \mathrm{mOsm} / \mathrm{kg}$ ( $p=0.08$, Tukey's HSD) after FW acclimation. A significant difference was found between the FW and SW groups $(p<0.05$, Tukey's HSD).

\section{Body fluid ion concentrations}

In the most marine L. semifasciata, body fluid $\left[\mathrm{Na}^{+}\right],\left[\mathrm{Cl}^{-}\right]$, and $\left[\mathrm{K}^{+}\right]$levels were $148.6 \pm 2,117.5 \pm 2$, and $4.6 \pm 1.2$ $\mathrm{mM}$, respectively, before transfer (Figures 2A, 3A, and 4A). After transfer to FW or SW, no significant change was found in these ionic concentrations $\left(\mathrm{Na}^{+}, F_{2,21}=2.06\right.$, $p=0.15 ; \mathrm{Cl}^{-}, F_{6,34}=0.85, p=0.44 ; \mathrm{K}^{+}, F_{2,19}=0.21$, $p=0.81$, ANOVA). In L. laticaudata, the body fluid $\left[\mathrm{Na}^{+}\right]$was $156.8 \pm 2 \mathrm{mM}$ before transfer (Figure 2B), and a significant difference was found between the FW $(153.1 \pm 1 \mathrm{mM})$ and SW $(161.3 \pm 1 \mathrm{mM})$ groups $(p<0.05$, Tukey's HSD). Body fluid $\left[\mathrm{Cl}^{-}\right]$was $118.8 \pm 3 \mathrm{mM}$ before transfer (Figure 3B), and a significant difference was found 


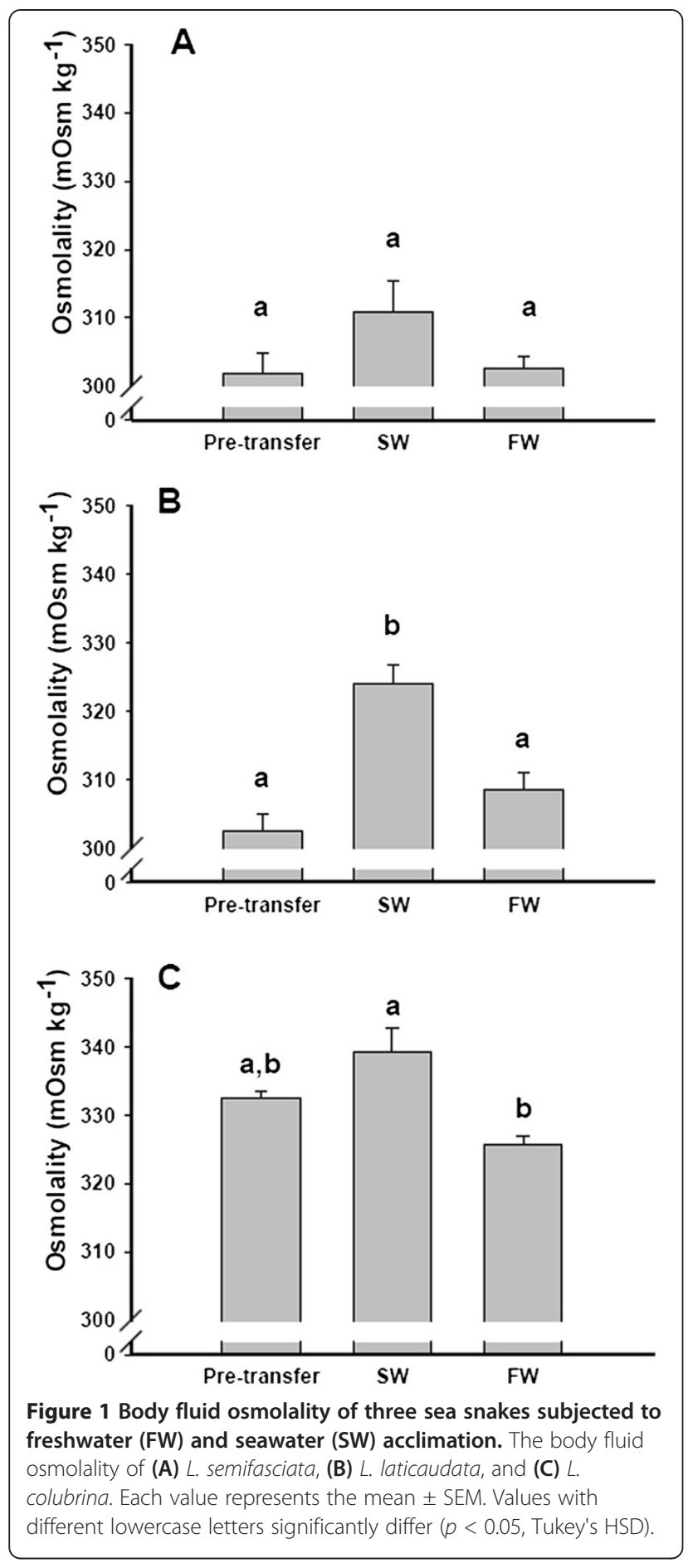

between the FW $(117 \pm 2 \mathrm{mM})$ and SW $(125.9 \pm 1 \mathrm{mM})$ groups $\left(p<0.05\right.$, Tukey's HSD). Body fluid $\left[\mathrm{K}^{+}\right]$was relatively constant, and no significant change was found after FW or SW acclimation $\left(F_{2,21}=2.02, p=0.16\right.$, ANOVA; Figure 4B). In the most terrestrial L. colubrina, $\left[\mathrm{Na}^{+}\right]$was $162 \pm 1 \mathrm{mM}$ before transfer (Figure $2 \mathrm{C}$ ), and no significant change was found after FW or SW
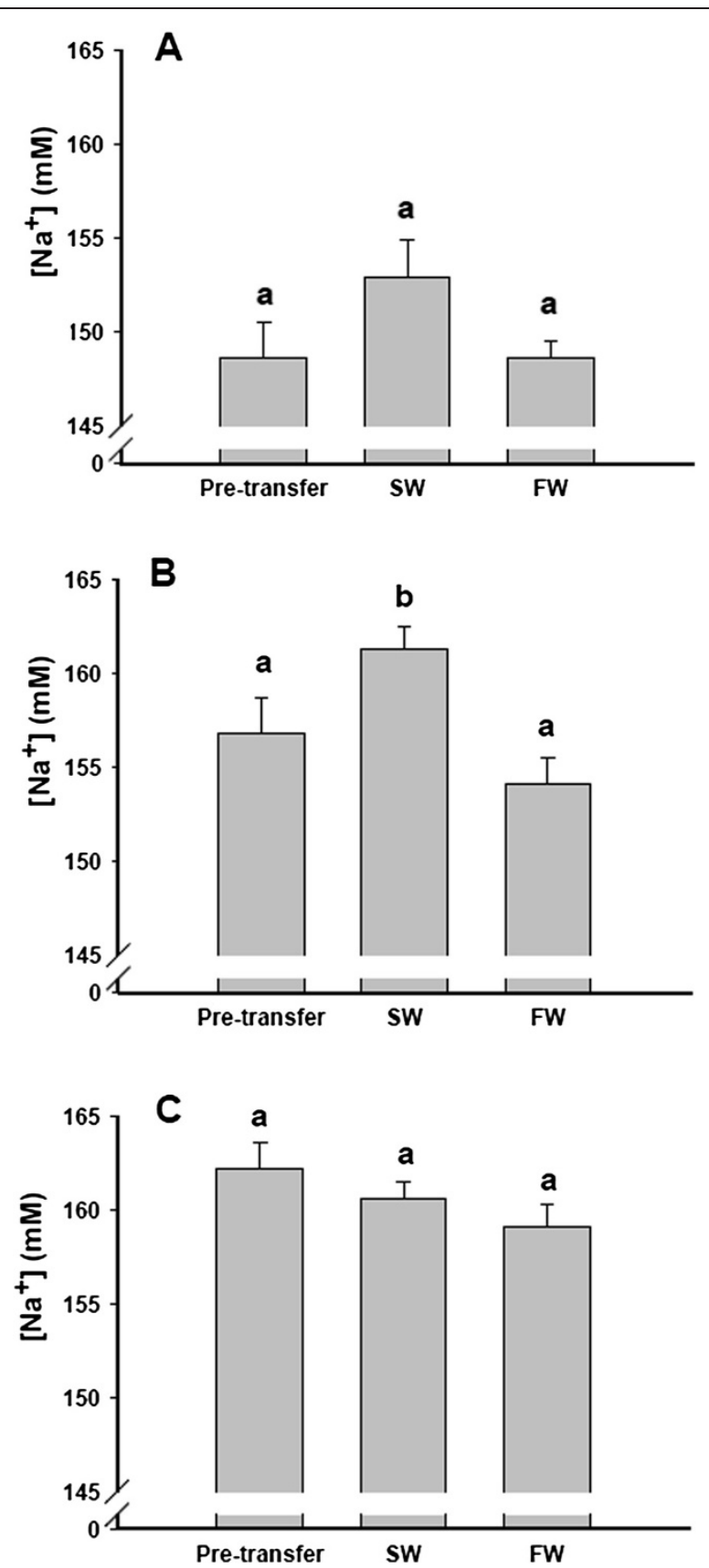

Figure 2 Body fluid $\left[\mathrm{Na}^{+}\right]$values of the three sea snakes subjected to freshwater (FW) and seawater (SW) acclimation. The body fluid $\left[\mathrm{Na}^{+}\right]$values of $(\mathbf{A})$ L. semifasciata, (B) L. laticaudata, and $(\mathbf{C}) L$. colubrina. Each value represents the mean \pm SEM. Values with different lowercase letters significantly differ $(p<0.05$, Tukey's HSD).

acclimation $\left(F_{2,16}=1.64, p=0.22\right.$, ANOVA $)$. Body fluid $\left[\mathrm{Cl}^{-}\right]$of $L$. colubrina was $120.2 \pm 2 \mathrm{mM}$ before transfer (Figure 3c), and it significantly increased after SW acclimation (127.7 $\pm 1 \mathrm{mM}, p<0.05$, Tukey's HSD), whereas no significant change was found after FW $(121.7 \pm 0.6 \mathrm{mM})$ acclimation $\left(p=0.7\right.$, Tukey's HSD). Body fluid $\left[\mathrm{K}^{+}\right]$ 


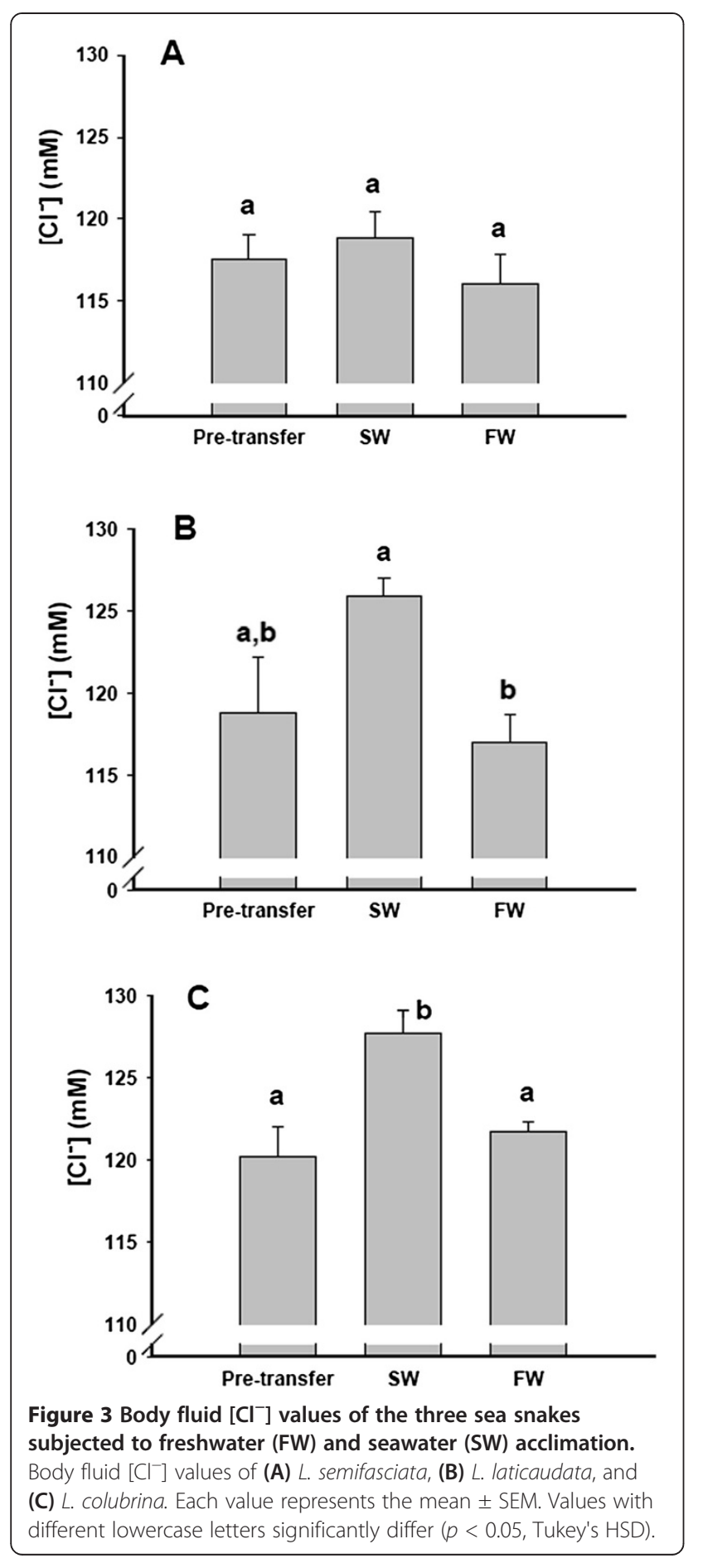

was $5.9 \pm 0.3 \mathrm{mM}$ before transfer (Figure $4 \mathrm{C}$ ), and no significant change was found after FW or SW acclimation $\left(F_{2,16}=1.19, p=0.33\right.$, ANOVA $)$.

\section{Muscle water content}

Muscle water content among the three species was similar, at $80 \%$ to $81 \%$ for $L$. semifasciata, $78 \%$ to $79 \%$
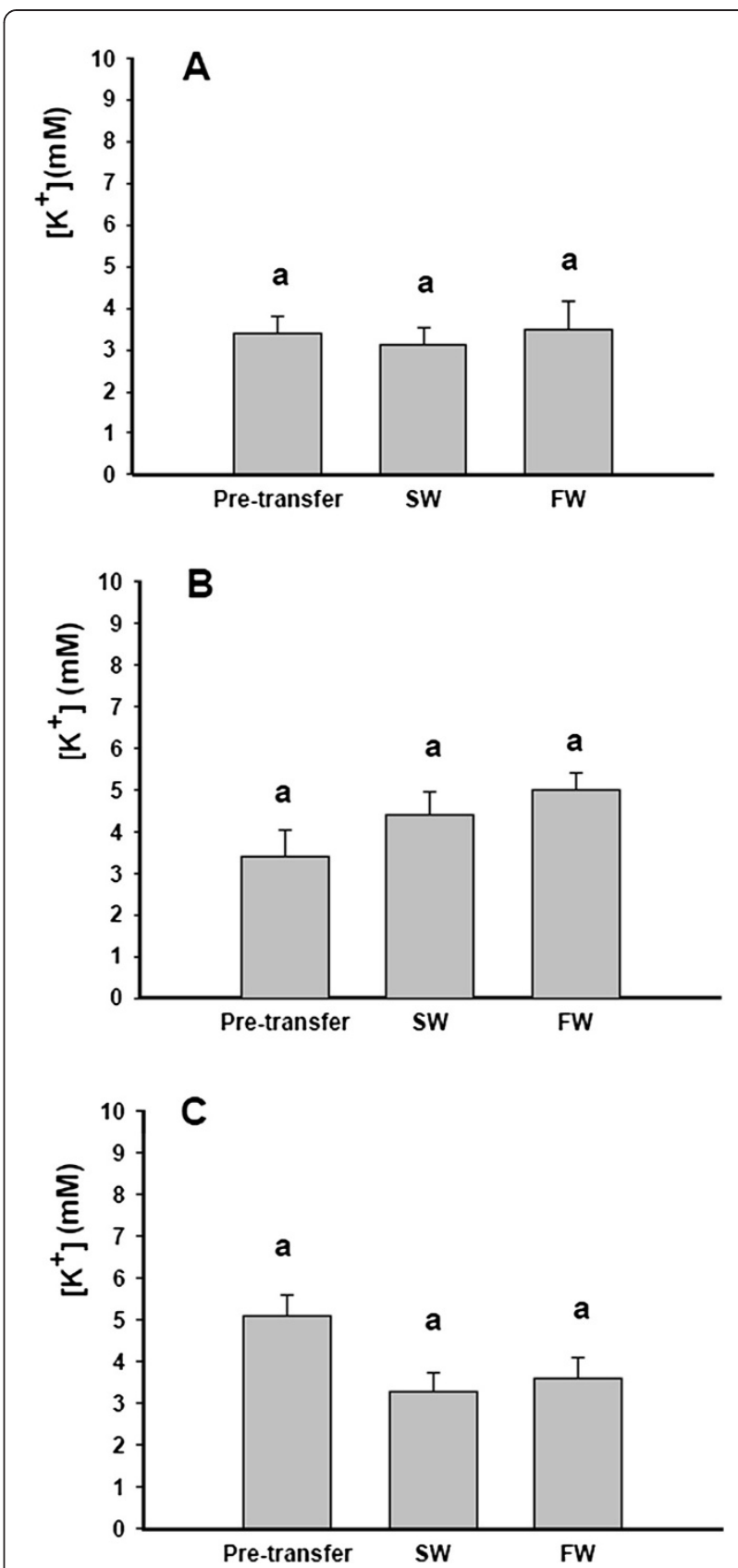

Figure 4 Body fluid $\left[\mathrm{K}^{+}\right]$values of the three sea snakes subjected to freshwater (FW) and seawater (SW) acclimation. Body fluid $\left[\mathrm{K}^{+}\right]$values of $(\mathbf{A}) \mathrm{L}$. semifasciata, (B) L. laticaudata, and (C) L. colubrina. Each value represents the mean \pm SEM.

for L. laticaudata, and $78.6 \%$ to $78.9 \%$ for L. colubrina. No significant change was found after FW or SW acclimation in the three species $\left(L\right.$. semifasciata, $F_{2,18}=1.34, p=0.84$, ANOVA, Figure 5A; $L$. laticaudata, $F_{2,18}=2.83, p=0.09$, ANOVA, Figure 5B; L. colubrina, $F_{2,16}=0.19, p=0.83$, ANOVA, Figure 5C). 


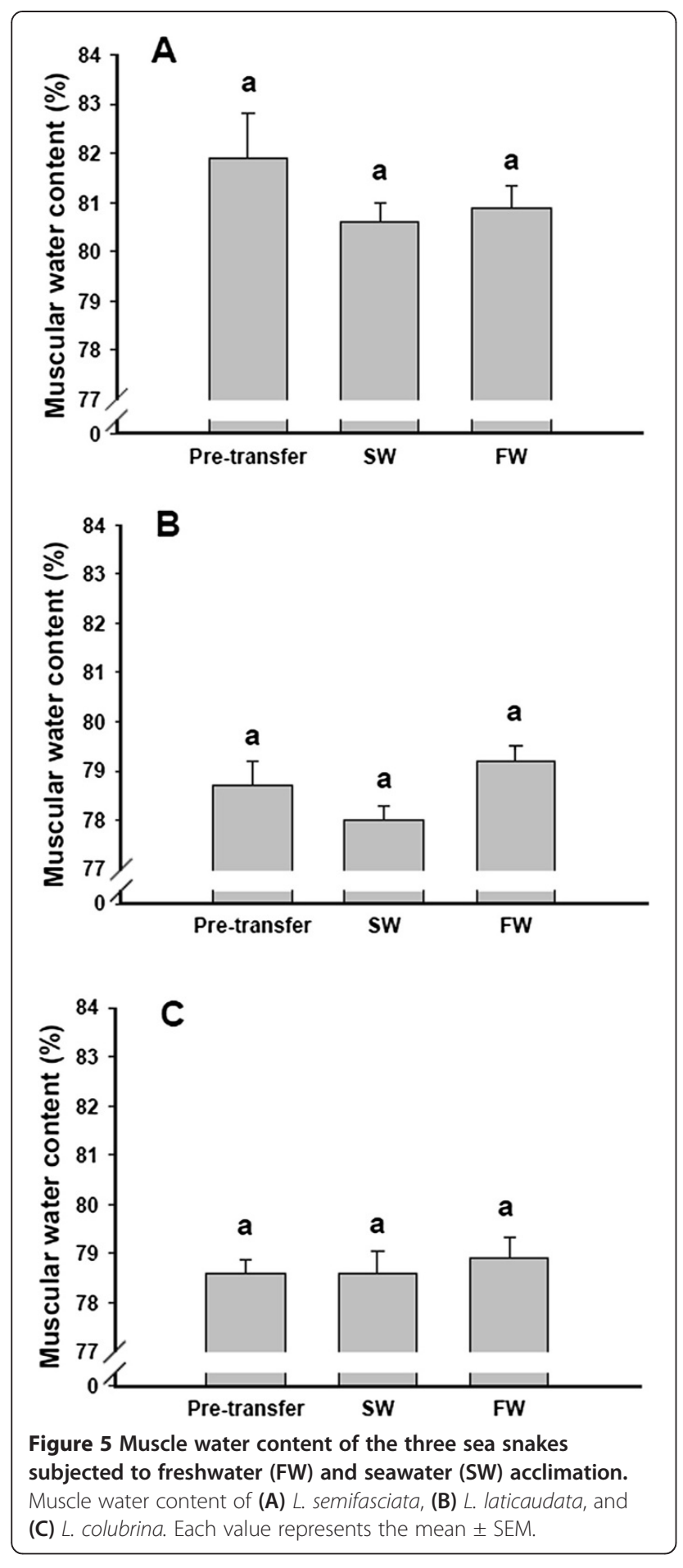

NKA activities of the salt gland

In L. semifasciata, NKA activity of the salt gland before transfer was significantly higher than those of the other species (31.6 $\pm 3 \mu \mathrm{mol} \mathrm{Pi} / \mathrm{mg} /$ protein $/ \mathrm{h} ; p<0.001$, Tukey's HSD, Figure 6A). It did not significantly change after SW acclimation $(32.6 \pm 3 \mu \mathrm{mol} \mathrm{Pi} / \mathrm{mg} /$ protein $/ \mathrm{h} ; p=0.9$, Tukey's HSD). However, it significantly decreased to
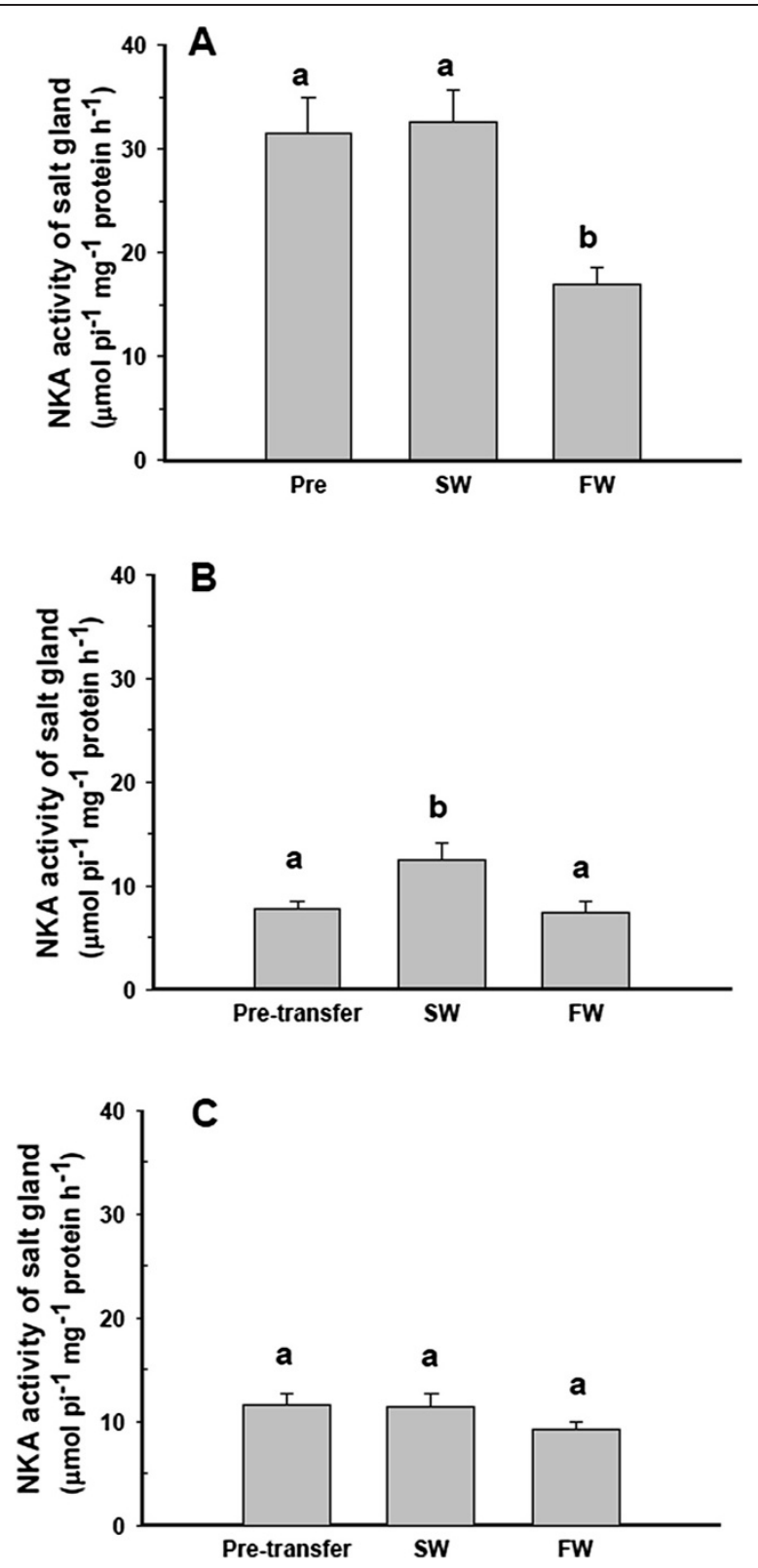

Figure 6 Salt gland $\mathrm{Na}^{+} / \mathrm{K}^{+}$-ATPase (NKA) activities of the three sea snakes subjected to freshwater (FW) and seawater (SW) acclimation. Salt gland $\mathrm{Na}^{+} / \mathrm{K}^{+}$-ATPase (NKA) activities of (A) $\mathrm{L}$. semifasciata, (B) L. laticaudata, and (C) L. colubrina. Each value represents the mean \pm SEM. Values with different lowercase letters significantly differ ( $p<0.05$, Tukey's HSD).

$17.0 \pm 2 \mu \mathrm{mol} \mathrm{Pi} / \mathrm{mg} /$ protein/h after FW acclimation $(p<$ 0.05 , Tukey's HSD). The NKA activity of L. laticaudata was $7.1 \pm 0.5 \mu \mathrm{mol} \mathrm{Pi} / \mathrm{mg} /$ protein/h before transfer (Figure 6b). It did not significantly change after FW acclimation $(7.5 \pm 1 \mu \mathrm{mol} \mathrm{Pi} / \mathrm{mg} /$ protein $/ \mathrm{h} ; p=0.9$, Tukey's HSD), but it significantly increased to $12.5 \pm 2$ $\mu \mathrm{mol} \mathrm{Pi} / \mathrm{mg} /$ protein/h after SW acclimation $(p<0.05$, Tukey's HSD). In L. colubrina, the NKA activity of the 
salt gland was $11.6 \pm 1 \mu \mathrm{mol} \mathrm{Pi} / \mathrm{mg} /$ protein/h before transfer (Figure 6c). However, no significant difference was found after FW or SW acclimation $\left(F_{2,15}=1.89\right.$, $p=0.18$, ANOVA).

\section{NKA activities of the kidneys}

The NKA activity of the kidneys was lower than that of the salt glands in all species before transfer (L. semifasciata, $3.4 \pm 0.4 \mu \mathrm{mol} \mathrm{Pi} / \mathrm{mg} / \operatorname{protein} / \mathrm{h}, p<0.001, t$ test; L. laticaudata, $3.4 \pm 0.6 \mu \mathrm{mol} \mathrm{Pi} / \mathrm{mg} /$ protein $/ \mathrm{h}, p<0.001$, $t$ test; L. colubrina, $5.1 \pm 0.5 \mu \mathrm{mol} \mathrm{Pi} / \mathrm{mg} /$ protein $/ \mathrm{h}, p<$ $0.001, t$ test). In addition, no significant change was found after FW or SW acclimation in the three species (L. semifasciata, $F_{2,18}=0.21, p=0.81$, ANOVA, Figure 7A; L. laticaudata, $F_{2,21}=1.42, p=0.26$, ANOVA, Figure 7B; L. colubrina, $F_{2,15}=3.29, p=0.07$, ANOVA, Figure 7C).

\section{Discussion}

The sea snakes are usually subdivided into two subfamilies (the Hydrophiidae and Laticaudinae) which originated from terrestrial elapid ancestors. However, the two subfamilies do not form a monophyletic group; instead, they represent two separate marine invasions in evolutionary history (Keogh 1998). The Hydrophiidae is comprised of fully marine species. However, the Laticaudinae (including one genus and eight species) is comprised of amphibious sea snakes (Cogger and Heatwole 2006) that forage in the sea but return to land to digest food, shed their skins, rest, and reproduce (Heatwole 1999; Brischoux et al. 2007; Brischoux and Bonnet 2009).

The three sea snakes (L. semifasciata, L. laticaudata, and L. colubrina) in Taiwan are also amphibious species, and they prefer to rest on coastal reefs with freshwater fountains (Liu et al. 2012). A previous study (Lillywhite et al. 2008) measured the dehydration rates of the three species when they were out of water and found no difference between $L$. semifasciata and L. laticaudata, whereas that of the $L$. colubrina was significantly lower than those of the other two species. Surprisingly, the dehydrated sea snakes were found to drink diluted SW but not full-strength SW. The salinities of the water they chose to drink also differed; L. semifasciata drank $30 \% \mathrm{SW}$, L. laticaudata drank $20 \%$ SW, and L. colubrina drank the most diluted SW (10\%). This finding explains why these species prefer to stay on coastal reefs with freshwater fountains. In the present study, we further found differences in their osmoregulatory abilities. In the most marine species, $L$. semifasciata, osmolality, $\left[\mathrm{Na}^{+}\right]$, and $\left[\mathrm{Cl}^{-}\right]$ were relatively constant after FW and SW acclimation (Figures 1, 2, and 3). However, in L. laticaudata and L. colubrina, osmolality, $\left[\mathrm{Na}^{+}\right]$, and $\left[\mathrm{Cl}^{-}\right]$significantly increased after SW acclimation, and values of these parameters in the SW groups were significantly higher than those in the FW groups (Figures 1, 2, and 3). These
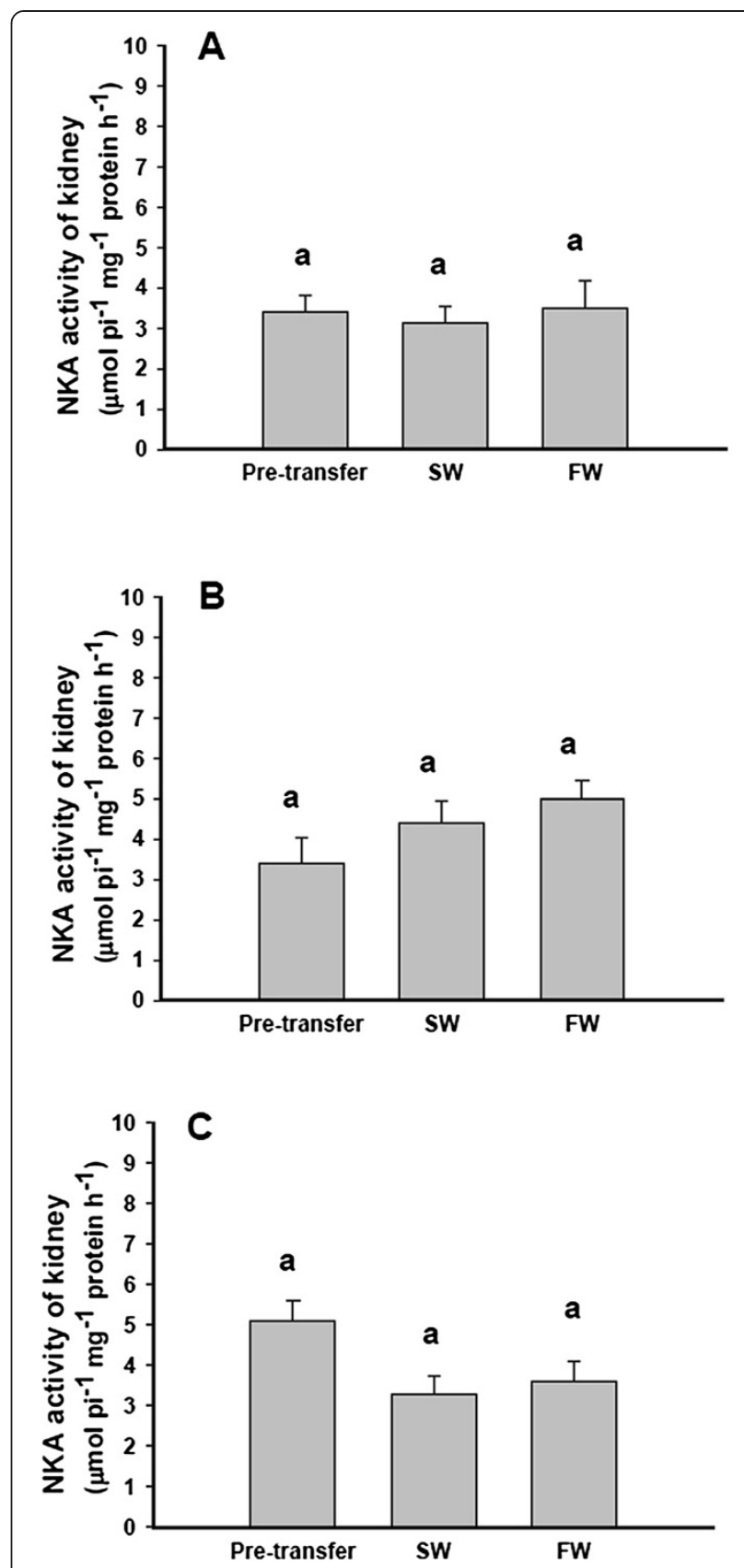

Figure 7 Renal $\mathrm{Na}^{+} / \mathrm{K}^{+}$-ATPase (NKA) activities of the three sea snakes subjected to freshwater (FW) and seawater (SW) acclimation. Renal $\mathrm{Na}^{+} / \mathrm{K}^{+}$-ATPase (NKA) activities of (A) $L$. semifasciata, (B) L. laticaudata, and (C) L. colubrina. Each value represents the mean \pm SEM.

results suggest that the three sea snakes have different osmoregulatory capabilities or strategies to respond to osmotic challenges.

Compared to euryhaline teleosts (Jensen et al. 1998; Kelly and Woo 1999; Lin et al. 2004a, b, 2006; Scott et al. 2006; Chew et al. 2009; Huang et al. 2010), fluctuations in body fluid osmolality and ionic concentrations were relatively 
small in the three sea snakes subjected to salinity challenges. Changes in osmolality are about 50 to $100 \mathrm{mOsm} /$ $\mathrm{kg}$ in teleosts, whereas they were only about $20 \mathrm{mOsm} / \mathrm{kg}$ in these sea snakes (Figure 1). In teleosts, the problem of osmotic and ionic gradients is exacerbated by the presence of the gill epithelium, a large, thin tissue used for efficient gas exchange and passive movement of water and salts (Evans et al. 2005). In contrast, the sea snakes are air breathers, and their skin is impermeable to $\mathrm{Na}^{+}$and slightly permeable to water (Dunson and Robinson 1976; Lillywhite et al. 2009). Therefore, the body fluid osmolality and ionic composition were relatively stable in these sea snakes subjected to salinity changes.

NKA plays a critical role in salt secretion by branchial MRCs of marine teleosts (Hwang and Lee 2007). It is well documented that euryhaline teleosts regulate branchial NKA activity in response to salinity changes (Marshall 2002; Evans et al. 2005). In euryhaline teleosts such as salmon (Tipsmark et al. 2002), eel (Wilson et al. 2007), tilapia (Lin et al. 2004a), and spotted green pufferfish (Lin et al. 2004b), branchial NKA activity was reported to increase in response to hypertonic acclimation. In euryhaline elasmobranches such as the bull shark Carcharhinus leucas and Atlantic stingray Dasyatis sabina, NKA activity of the rectal salt gland was significantly higher in SW than in FW (Piermarini and Evans 2000; Pillans et al. 2005). In sea snakes, NKA activities of the salt gland in several species were reported in early studies (Dusnson and Dunson 1974). However, little is known about the regulation of NKA activity in the sea snakes subjected to salinity changes. In an early report (Dunson and Dunson 1975), no significant difference was found in salt gland NKA activity of the yellow-bellied sea snake Pelamis platurus acclimated to SW and FW. In this study, we found that NKA activity was higher in $\mathrm{SW}$-acclimated than in FW-acclimated $L$. semifasciata and L. laticaudata (Figure 6), suggesting that NKA is critical and upregulated for salt secretion by the sublingual salt gland. Interestingly, responses of salt gland NKA activities to salinity changes varied among the three species, suggesting that they might have different strategies to cope with osmotic challenges.

In the most marine L. semifasciata, the NKA activity of the salt gland was approximately threefold higher than those of the other species before transfer, and it was downregulated after transfer to FW (Figure 6A) but did not significantly change after transfer to SW. We suggest that this species has high NKA activity and a high salt-secreting capability to cope with SW challenges, and this capability is associated with its marine affinity. With a high salt-secreting capability, it can drink 30\% seawater (Lillywhite et al. 2008) and excrete redundant salt. On the other hand, it can still maintain its osmolality and ionic levels in FW, indicating that hypotonic water is not a limiting factor of its distribution.

In the most terrestrial L. colubrina, NKA activity was lower than that of the L. semifasciata and did not respond to SW or FW acclimation, implying that L. colubrina might have a low capability to excrete salt (Figure 6C). However, its osmolality and ionic concentrations remained relatively constant after acclimation. Since this species has a lower skin permeability to water than the other two species (Lillywhite et al. 2009), it might also have low permeability to salt and use a passive strategy to cope with osmotic challenges instead of an active regulatory strategy. In the wild, it probably drinks low-salinity water from freshwater fountains and stays on land a longer time to prevent salt loading. In addition, only $\left[\mathrm{Cl}^{-}\right]$but not $\left[\mathrm{Na}^{+}\right]$was elevated in $L$. colubrine after transfer to $\mathrm{SW}$, suggesting that $L$. colubrine might have a lower permeability to $\mathrm{Na}^{+}$than to $\mathrm{Cl}^{-}$.

Due to lacking Henle's loop, marine teleosts, elasmobranches, and reptiles cannot produce highly concentrated urine (Hill et al. 2004). In marine reptiles, early studies suggested that the kidneys of the saltwater crocodile Crocodylus porosus and olive sea snake Aipysurus laevis are the primary site of sodium and water reabsorption rather than salt excretion (Benyajati et al. 1985; Yokota et al. 1985; Kuchel and Franklin 1998). In addition, a recent study on $L$. semifasciata and other marine snakes showed that the distribution and abundance of the NKA protein and messenger RNA in the kidneys did not significantly change after salinity acclimation (Babonis et al. 2011). In the present study, the renal NKA activity of the kidneys was lower than that of the salt gland and did not respond to salinity changes (Figure 7), supporting the kidneys not being involved in salt secretion in sea snakes.

\section{Conclusions}

This study suggests that the NKA activity of the sublingual gland is associated with salt excretion, and the three species possess different osmoregulatory strategies which are associated with their habitat affinities.

\section{Competing interests}

The authors declare that they have no competing interests.

\section{Authors' contributions}

YCC carried out the most experiments and drafted the manuscript. MCT participated in the design of the study. JRT carried out a portion of the NKA activity assays. HCL participated in the design of experiments. LYL conceived of the study and participated in its design and coordination. All authors read and approved the final manuscript.

\section{Acknowledgements}

We thank Dr. Yeong-Choy Kam and Dr. Tsung-Han Lee for supplying the osmometer and Dr. Leslie S. Babonis for the anatomical knowledge. This work was support by a grant (NSC97-2621-B-003-004-MY3) from the National Science Council, Taiwan. 


\section{Author details}

'Department of Life Science, National Taiwan Normal University, Taipei 116, Taiwan. ${ }^{2}$ Department of Life Science, Tunghai University, Taichung 40704, Taiwan. ${ }^{3}$ Center for Tropical Ecology and Biodiversity, Tunghai University, Taichung 40704, Taiwan.

Received: 29 November 2012 Accepted: 14 June 2013 Published: 4 October 2013

\section{References}

Babonis LS, Hyndman KA, Lillywhite HB, Evans DH (2009) Immunolocalization of $\mathrm{Na}^{+} / \mathrm{K}^{+}$-ATPase and $\mathrm{Na}^{+} / \mathrm{K}^{+} / 2 \mathrm{Cl}^{-}$cotransporter in the tubular epithelia of sea snake salt glands. Compar Biochem Physiol A 154:535-540

Babonis LS, Miller SN, Evans DH (2011) Renal responses to salinity change in snakes with and without salt glands. J Exp Biol 214:2140-2156

Benyajati S, Yokota SD, Dantzler WH (1985) Renal function in sea snakes. II. Sodium, potassium, and magnesium excretion. Am J Physiol Regul Integr Compar Physiol 249:R237-R245

Brischoux F, Bonnet X (2009) Life history of sea kraits in New Caledonia. Mem Mus Nat Hist Nat 198:133-146

Brischoux F, Bonnet X, Shine R (2007) Foraging ecology of sea kraits (Laticauda spp.) in the Neo-Caledonian lagoon. Mar Ecol Progr Ser 350:145-151

Burger JW (1965) Roles of the rectal gland and kidneys in salt and water excretion in the spiny dogfish. Physiol Zool 38:191-196

Chew SF, Tng YYM, Wee NLJ, Wilson JM, Ip YK (2009) Nitrogen metabolism and branchial osmoregulatory acclimation in the juvenile marble goby, Oxyeleotris marmorata, exposed to seawater. Compar Biochem Physiol A 154:360-369

Cogger H, Heatwole H (2006) Laticauda frontalis (de Vis, 1905) and Laticauda saintgironsi n. sp. from Vanuatu and New Caledonia (Serpentes: Elapidae: Laticaudinae) - a new lineage of sea kraits? Rec Aust Mus 58:245-256

Dunson WA (1969) Electrolyte excretion by the salt gland of the Galapagos marine iguana. Am J Physiol 216:995-1002

Dunson WA (1970) Some aspects of electrolyte and water balance in three estuarine reptiles, the diamondback terrapin, American and "salt water" crocodiles. Compar Biochem Physiol 32:161-174

Dunson WA, Dunson MK (1973) Convergent evolution of sublingual salt glands in the marine file snake and the true sea snakes. J Compar Physiol 86:193-208

Dunson WA, Dunson MK (1974) Interspecific differences in fluid concentration and secretion rate of sea snake salt glands. Am J Physiol 227:430-438

Dunson MK, Dunson MA (1975) The relation between plasma Na concentration and salt gland Na-K ATPase content in the diamondback terrapin and the yellow-bellied sea snake. J Compar Physiol 101:89-97

Dunson WA, Dunson MK (1979) A possible new salt gland in marine homalopsid snake (Cerberus rhynchops). Copeia 1979:661-672

Dunson WA, Robinson GD (1976) Sea snake skin: permeable to water but not to sodium. J Compar Physiol B 108:303-311

Dunson WA, Packer RK, Dunson MK (1971) Sea snakes: an unusual salt gland under the tongue. Science 173:437-441

Evans DH, Piermarini PM, Choe KP (2005) The multifunctional fish gill: dominant site of gas exchange, osmoregulation, acid-base regulation, and excretion of nitrogenous waste. Physiol Rev 85:97-177

Heatwole H (1999) Sea snakes. Krieger Publishing, Malabar, pp 30-45

Hildebrandt JP (2001) Coping with excess salt: adaptive functions of extrarenal osmoregulatory organs in vertebrates. Zoology 104:209-220

Hill RW, Wyse GA, Anderson M (2004) Animal physiology. Sinauer Associates, Sunderland, pp 685-719

Huang CY, Chao PL, Lin HC (2010) $\mathrm{Na}^{+} / \mathrm{K}^{+}$-ATPase and vacuolar-type $\mathrm{H}^{+}$-ATPase in the gills of the aquatic air-breathing fish Trichogaster microlepis in response to salinity variation. Compar Biochem Physiol A 155:309-318

Hudson DM, Lutz PL (1986) Salt gland function in the leatherback sea turtle, Dermochelys coriacea. Copeia 1986:247-249

Hwang PP, Lee TH (2007) New insights into fish ion regulation and mitochondrion-rich cells. Compar Biochem Physiol A 148:479-497

Jensen MK, Madsen SS, Kristiansen K (1998) Osmoregulation and salinity effects on the expression and activity of $\mathrm{Na}^{+}, \mathrm{K}^{+}$-ATPase in the gills of European sea bass, Dicentrarchus labrax (L.). J Exp Zool 282:290-300
Kelly SP, Woo NYS (1999) The response of sea bream following abrupt hyposmotic exposure. J Fish Biol 55:732-750

Keogh J (1998) Molecular phylogeny of elapid snakes and a consideration of their biogeographic history. Biol J Linn Soc 63:177-203

Kuchel LJ, Franklin CE (1998) Kidney and cloaca function in the estuarine crocodile (Crocodylus porosus) at different salinities: evidence for solute-linked water uptake. Compar Biochem Physiol A 119:825-831

Lillywhite HB, Babonis LS, Tu MC (2008) Sea snakes (Laticauda spp.) require fresh drinking water: implication for the distribution and persistence of populations. Physiol Biochem Zool 81:785-796

Lillywhite HB, Menon JG, Menon GK, Sheehy CM 3rd, Tu MC (2009) Water exchange and permeability properties of the skin in three species of amphibious sea snakes (Laticauda spp.). J Exp Biol 212:1921-1929

Lin $\mathrm{CH}$, Huang $\mathrm{CL}$, Yang CH, Lee TH, Hwang PP (2004a) Time-course changes in the expression of $\mathrm{Na}$, K-ATPase and the morphometry of mitochondrion-rich cells in gills of euryhaline tilapia (Oreochromis mossambicus) during freshwater acclimation. J Exp Zool A 301:85-96

Lin CH, Tsai RS, Lee TH (2004b) Expression and distribution of $\mathrm{Na}^{+}$, $\mathrm{K}^{+}$-ATPase in gill and kidney of the spotted green pufferfish, Tetraodon nigroviridis, in response to salinity challenge. Compar Biochem Physiol A 138:287-295

Lin YM, Chen CN, Yoshinaga T, Tsai SC, Shen ID, Lee TH (2006) Short-term effects of hyposmotic shock on $\mathrm{Na}^{+} / \mathrm{K}^{+}$-ATPase expression in gills of the euryhaline milkfish. Chanos chanos Compar Biochem Physiol A 143:406-415

Liu YL, Chen YH, Lillywhite HB, Tu MC (2012) Habitat selection by sea kraits (Laticauda spp.) at coastal sites of Orchid Island. Taiwan Integr Compar Biol 52:274-280

Marshall WS (2002) $\mathrm{Na}^{+}, \mathrm{Cl}^{-}, \mathrm{Ca}^{2+}$ and $\mathrm{Zn}^{2+}$ transport by fish gills: retrospective review and prospective synthesis. J Exp Zool 293:264-283

Oguri M (1964) Rectal glands of marine and fresh-water sharks: comparative histology. Science 144:1151-1152

Peaker M (1971) Avian salt glands. Phil Trans Roy Soc Lond B 262:289-300

Piermarini PM, Evans DH (2000) Effects of environmental salinity on $\mathrm{Na}^{+} / \mathrm{K}$ ${ }^{+}$-ATPase in the gills and rectal gland of a euryhaline elasmobranch (Dasyatis sabina). J Exp Biol 203:2957-2966

Pillans RD, Good JP, Anderson WG, Hazon N, Franklin CE (2005) Freshwater to seawater acclimation of juvenile bull sharks (Carcharhinus leucas): plasma osmolytes and $\mathrm{Na}^{+} / \mathrm{K}^{+}$-ATPase activity in gill, rectal gland, kidney and intestine. J Compar Physiol B 175:37-44

Riordan JR, Forbush B, Hanrahan JW (1994) The molecular basis of chloride transport in shark rectal gland. J Exp Biol 196:405-418

Schmidt-Nielsen K (1958) Salt gland in marine reptile. Nature 182:782-785

Schmidt-Nielsen K (1960) The salt-secreting gland of marine birds. Circulation 21:955-967

Scott GR, Schulte PM, Wood CM (2006) Plasticity of osmoregulatory function in the killifish intestine: drinking rates, salt and water transport, and gene expression after freshwater transfer. J Exp Biol 209:4040-4050

Shetty S, Shine R (2002) Philopatry and homing behavior of sea snakes (Laticauda colubrina) from two adjacent islands in Fiji. Conserv Biol 16:1422-1426

Shuttleworth TJ, Hildebrandt JP (1999) Vertebrate salt glands: short- and longterm regulation of function. J Exp Zool 283:689-701

Silva P, Solomon RJ, Epstein FH (1997) Transport mechanisms that mediate the secretion of chloride by the rectal gland of Squalus acanthias. J Exp Zool 279:504-508

Taplin LE, Grigg GC (1981) Salt glands in the tongue of the estuarine crocodile Crocodylus porosus. Science 212:1045-1047

Tipsmark CK, Madsen SS, Seidelin M, Christensen AS, Cutler CP, Cramb G (2002) Dynamics of $\mathrm{Na}^{+}, \mathrm{K}^{+}, 2 \mathrm{Cl}^{-}$cotransporter and $\mathrm{Na}^{+}, \mathrm{K}^{+}$-ATPase expression in the branchial epithelium of brown trout (Salmo trutta) and Atlantic salmon (Salmo salar). J Exp Zool A 293:106-118

Tsai JR, Lin HC (2007) V-type $\mathrm{H}^{+}$-ATPase and $\mathrm{Na}^{+}, \mathrm{K}^{+}$-ATPase in the gills of 13 euryhaline crabs during salinity acclimation. J Exp Biol 210:620-627

Vermeij GJ, Dudley R (2000) Why are there so few evolutionary transitions between aquatic and terrestrial ecosystems? Biol J Linn Soc 70:541-554 
Willmer P, Stone G, Johnson I (2004) Environmental physiology of animals. Blackwell Publishing, Malden, pp 393-443

Wilson JM, Leitao A, Goncalves AF, Ferreira C, Reis-Santos P, Fonseca AV, da Silva JM, Antunes JC, Pereira-Wilson C, Coimbra J (2007) Modulation of branchial ion transport protein expression by salinity in glass eels (Anguilla anguilla L.). Mar Biol 151:1633-1645

Yokota SD, Benyajati S, Dantzler WH (1985) Renal function in sea snakes. I. Glomerular filtration rate and water handling. Am J Physiol Regul Integr Compar Physiol 249:R228-R236

doi:10.1186/1810-522X-52-28

Cite this article as: Cheng et al:: Comparison of the osmoregulatory

capabilities among three amphibious sea snakes (Laticauda spp.)

in Taiwan. Zoological Studies 2013 52:28.

\section{Submit your manuscript to a SpringerOpen ${ }^{\circ}$} journal and benefit from:

- Convenient online submission

$\checkmark$ Rigorous peer review

- Immediate publication on acceptance

- Open access: articles freely available online

- High visibility within the field

- Retaining the copyright to your article

Submit your next manuscript at $>$ springeropen.com 